\title{
EMPIRICAL ANALYSIS OF THE RELATIONSHIP BETWEEN DEVELOPMENT OF RURAL FINANCIAL SYSTEM AND RURAL ECONOMIC GROWTH
}

\author{
JIAO JINPENG \\ Harbin University of Commerce MBA MPA Education Center, Harbin, China.
}

\begin{abstract}
This article investigates the relationship between the development of the rural financial system and the ACP economic growth. The vector error correction model, co-integration method and impulse response function are used to analyze the data. This article does the systematic empirical and quantitative research from the three aspects of the financial system: its scale, structure and efficiency. This research shows that it has the equilibrium co-integration relationship and long-term one-way Granger causality between them. That means rural financial system efficiency, rural financial deepening, and improvement of the structure of the rural financial system can increase the growth of rural economy, agricultural development and peasants' income significantly. Therefore, it is necessary to increase the efficiency of rural financial institutions and to improve the rural financial system structure and security of the rural financial system to maintain rural economic growth, agricultural development and farmers' income.
\end{abstract}

Keywords: Rural financial system, ACP economic, VEC model, co-integration.

\section{INTRODUCTION}

Rural finance is the core field of modern rural economy. There exist promotions and influence between rural financial system and rural economic development. A complete financial system can effectively mobilize social savings and transform it into investment to put into production quickly. Then, it will help in the development of economy and income growth. On the other hand, with the development of social economy and an increase in people's income, the demand of economy and society for financial services will also increase. This will promote the financial industry to improve its service system accordingly.

\section{LITERATURE REVIEW}

Han Tingchun [1] found that the efficiency representing the level of financial development had very important influence on economic growth by establishing the optimization model. Nie Hongshun [2] used multiple linear regression analysis to find the relationship between rural financial development and economic growth in Heilongjiang province. Yu YueJun [3] used 1978-2010 annual data to investigate the relationship between rural financial development and rural economic growth using vector autoregressive (VAR) model. Ding Zhiguo [4] analyzed the mutual influence between rural finance and rural economic development and stated the Chinese rural credit structure imbalance. Huang Yanxin [5] pointed out that the innovation of rural finance helped to improve rural financial services, but the rural financial reform still lagged behind the economic development of agriculture and rural areas.

Considering the research above, study of experience has two aspects of shortcomings. First, the analysis focuses only on the relationship between financial development and economic growth, ignoring empirical analysis of the relationship between rural financial system development and rural economic growth. Second, the analysis only investigates the relationship between rural economy growth and individual variables in the rural financial system. The research ignores the practice analysis from the overall development of rural financial system and rural economic growth. Therefore, 
this paper will use co-integration, error correction model and impulse response function to measure the dynamic relationship between rural financial system and rural economic growth comprehensively, based on the data from Heilongjiang province rural area.

\section{DATA SELECTION AND ECONOMETRIC MODEL}

\subsection{Construction and data processing}

The group of rural financial index system includes:

(1) The development scale of rural financial system - DS (development scale)

Considering that the rural finance in Heilongjiang province mainly depends on deposit and lending business; deposit mainly reflects the status of the rural capital source, and loans can reflect the rural financial support to agriculture, rural areas and farmers' economy. Therefore, the indicator reflecting the rural financial development scale is DS = rural loan balance/rural economic GDP. The rural loan balance is the sum of loan balance of township enterprises and agricultural loan balance. Rural economy GDP is the output value of the first industry.

(2) The development structure of rural financial system - DST (development structure)

Since the reform and opening up, the enterprises of township and villages in rural economy play an important role increasingly. Therefore, this article uses loan balance/rural township enterprises loan balance as indicators of financial development structure.

(3) The development efficiency of rural financial system - DE (development efficient)

The efficiency of financial system development mainly refers to the degree of financial institutions playing the role of financial intermediaries. Mobilization and use of savings are the most important functions of financial intermediation. And the measure of financial intermediary function mainly reflected the ability of reasonable savings transforming into investment in the financial institutions. Therefore, it is reasonable to use the ratio of rural loan balance and rural savings balance to measure the efficiency of financial system development in Heilongjiang Province.

3.2 The group of rural economic indicators

(1) The index of agricultural development: Heilongjiang province is a big agricultural province and the largest commodity grain base in China. The steady expansion of grain production in Heilongjiang province has significant and far-reaching meanings to promote new rural construction, develop modern agriculture and bring prosperity to rural economy. Therefore, the index of food production to represent agricultural development is chosen in this study.

(2) The index of rural economy development: Here, we use the total output value of the first industry to represent the development situation of rural economy.

(3) The indicators of farmers PI (pure income of farmers): The per capita net income index of rural farmers can reflect the productivity level of input and output efficiency. Therefore, we select the per capita net income of farmers in the first industry to reflect the farmers' income.

Then, we take the entire data log processed. First, its purpose is to reduce the heteroskedasticity of the data. Second, it helps estimate elastic coefficient between the variables. After processing with the rural financial system development scale, development of rural financial system structure, 
development of rural financial system efficiency, agricultural development, development of rural economy and increasing farmers' income, this article uses LnDS, LnDST, LnDE, LnAD, LnRE and LnPI to represent the variables.

\subsection{Econometric model}

Vector error correction (VEC) model is a VAR model containing co-integration. It is usually used for a non-stationary time series containing co-integration relationship.

$$
\Delta y_{t}=\operatorname{aecm}_{t-1}+\sum_{i=1}^{p-1} \Gamma_{i} \Delta y_{t-i}+\varepsilon_{t}, t=1,2, \cdots, T
$$

Each of these equations is an error correction model. Among them, $a e c m_{t-1}=\beta^{\prime} y_{t-1}$ is the error correction term, reflecting the long-term equilibrium relationship between variables directly. $a$ reflects the adjustment speed back to the equilibrium when the variable coefficient vector is deviating from the long-term equilibrium state.

\section{THE EMPIRICAL RESULTS OF THE ANALYSIS}

\subsection{Unit root test}

When non-stationary variables are used, regression may cause errors. To avoid this problem, we first adopt Dickey and Fuller's [6] ADF method for unit root test of all variables. The test results are shown in Table 1.

Table 1: Unit root test table.

\begin{tabular}{|c|c|c|c|c|c|c|c|c|c|}
\hline \multirow[b]{2}{*}{ Variables } & \multirow{2}{*}{$\begin{array}{c}\text { Test forms } \\
\qquad(c, t, k)\end{array}$} & \multirow{2}{*}{$\begin{array}{c}\text { ADF } \\
\text { values }\end{array}$} & \multicolumn{3}{|c|}{$\begin{array}{l}\text { Critical value under } \\
\text { significant level }\end{array}$} & \multirow[b]{2}{*}{ Probability* } & \multirow[b]{2}{*}{ AIC } & \multirow[b]{2}{*}{$\mathrm{SC}$} & \multirow{2}{*}{$\begin{array}{l}\text { Test } \\
\text { results }\end{array}$} \\
\hline & & & 0.01 & 0.05 & 0.1 & & & & \\
\hline LnDS & $(c, 0,1)$ & -2.12 & -3.68 & -2.97 & -2.62 & 0.24 & -3.02 & -2.88 & Unstable \\
\hline$\Delta \mathrm{LnDS}$ & $(c, 0,1)$ & -3.55 & -3.69 & -2.97 & -2.63 & 0.01 & -2.92 & -2.78 & Stable \\
\hline LnDST & $(c, 0,1)$ & -2.12 & -3.68 & -2.97 & -2.62 & 0.24 & -3.02 & -2.88 & Unstable \\
\hline$\Delta \operatorname{LnDST}$ & $(c, 0,1)$ & -3.58 & -2.65 & -1.95 & -1.61 & 0.00 & -2.98 & -2.89 & Stable \\
\hline LnDE & $(c, t, 0)$ & -0.59 & -4.30 & -3.57 & -3.22 & 0.97 & -2.74 & -2.60 & Unstable \\
\hline$\Delta \mathrm{LnDE}$ & $(c, 0,0)$ & -4.05 & -3.68 & -2.97 & -2.62 & 0.00 & -2.72 & -2.62 & Stable \\
\hline LnAD & $(c, t, 0)$ & -3.49 & -4.30 & -3.57 & -3.22 & 0.06 & -1.42 & -1.28 & Unstable \\
\hline$\Delta \mathrm{LnAD}$ & $(c, t, 0)$ & -7.05 & -4.31 & -3.57 & -3.22 & 0.00 & -1.11 & -0.97 & Stable \\
\hline LnRE & $(c, t, 0)$ & -2.84 & -4.32 & -3.58 & -3.23 & 0.20 & -1.20 & -0.96 & Unstable \\
\hline$\Delta \mathrm{LnRE}$ & $(c, 0,0)$ & -4.26 & -3.68 & -2.97 & -2.62 & 0.00 & -1.10 & -1.01 & Stable \\
\hline LnPI & $(c, t, 2)$ & -2.19 & -4.32 & -3.58 & -3.23 & 0.48 & -1.21 & -0.98 & Unstable \\
\hline$\Delta \mathrm{LnPI}$ & $(c, 0,1)$ & -3.16 & -3.69 & -2.97 & -2.63 & 0.03 & -1.15 & -1.00 & Stable \\
\hline
\end{tabular}


From the results of unit root test, we found that the variable sequence given in Table 1 is not smooth below the 5\% level of significance, but the first-order differential sequence is smooth. It means that they are integrated sequences of order 1, I(1). And there may be a co-integration relationship among the variables.

\subsection{The structure of the VAR model}

The linear group containing same number of non-stationary variables can be smooth, according to the co-integration theory proposed by Engle and Granger [7]. The smooth linear combination is known as co-integration equation, and it reveals the long-term stable equilibrium relationship between the variables. Two or more of the co-integration relationship between non-stationary variables can be tested in the Johansen co-integration test. This method is based on VAR model; in a test, we must first determine the structure of the VAR model.

According to the AIC and SC information rules, the most appropriate lag $K$ value is determined by the VAR model. As shown in Table 1 , although we know that by SC rules, $K=1$, with AIC, FPE, and LR judgment, $K=2$. By residual test, this passage finally chose lag $K=2$. At this point, all reciprocal values of root of characteristic equation are in the unit circle. Therefore, the VAR model is stable.

\subsection{Johansen co-integration test}

The Johansen co-integration test is the constrained VAR model. As a result, the optimal lag Johansen co-integration test should be less than the optimal lag period of the corresponding VAR model. Because the optimal lag of VAR model is 2, the lag of the Johansen co-integration test is determined as 1 .

From Table 2, the trace tests and the maximum characteristic root test showed that: at the 95\% confidence level, there exist two co-integration equations among the variables LnDS, LnDST, LnDE, LnAD, LnRE and LnPI. After normalization, the long-term co-integration relationship can be represented as

$$
\operatorname{LnAD}=9.404-1.652 \underset{[-9.74]}{\operatorname{LnDS}}-0.063 \underset{[-7.04]}{\operatorname{LnDST}}+1.309 \underset{[7.69]}{\operatorname{LnDE}}+0.186 \underset{[2.40]}{\operatorname{LnRE}}-0.135 \underset{[-1.41]}{\operatorname{LnPI}}
$$

Table 2: The Johansen co-integration test results.

\begin{tabular}{|c|c|c|c|c|c|c|c|}
\hline \multirow{2}{*}{$\begin{array}{l}\text { Assumptions } \\
\text { Number of } \\
\text { co-integration } \\
\text { equations }\end{array}$} & \multirow[b]{2}{*}{$\begin{array}{c}\text { Flag } \\
\text { values }\end{array}$} & \multicolumn{3}{|c|}{ Statistic tests } & \multicolumn{3}{|c|}{ Characteristic root statistic test } \\
\hline & & $\begin{array}{c}\text { Trace } \\
\text { statistics }\end{array}$ & $P$-value** & $\begin{array}{c}\text { Critical } \\
\text { value } 5 \%\end{array}$ & $\begin{array}{l}\text { Characteristic } \\
\text { root statistics }\end{array}$ & $P$-value** & $\begin{array}{c}\text { Critical } \\
\text { value } 5 \%\end{array}$ \\
\hline None $* \&$ & 0.89 & 163.18 & 0.00 & 95.75 & 64.19 & 0.00 & 40.08 \\
\hline 1 at most*\& & 0.83 & 99.00 & 0.00 & 69.82 & 50.68 & 0.00 & 33.88 \\
\hline 2 at most* & 0.59 & 48.32 & 0.05 & 47.86 & 25.89 & 0.08 & 27.58 \\
\hline 3 at most & 0.38 & 22.43 & 0.28 & 29.80 & 13.72 & 0.39 & 21.13 \\
\hline 4 at most & 0.26 & 8.71 & 0.39 & 15.49 & 8.68 & 0.31 & 14.26 \\
\hline 5 at most & 0.00 & 0.03 & 0.86 & 3.84 & 0.03 & 0.86 & 3.84 \\
\hline
\end{tabular}


The co-integration analysis results show that a long-term equilibrium relationship between the two groups of variables, rural economic development and the development of the rural financial system in Heilongjiang province, exists. Among the variables, there is a positive correlation between the agricultural development and the rural economic growth. But the increase in farmers' income plays a negative role in agricultural development, and this is different from the usual understanding. This phenomenon has the following reasons: on the one hand, variable $t$-test is not $>2$; farmers' income is significantly less than the problem. On the other hand, we can conclude that the rural incomes in nearly 4 years of main trend, farm incomes of farmers' income the proportion of slow decline continuously, at the same time spending on farmers in agricultural production and the proportion of is also declined year by year.

The scale and the structure of rural financial system have negative effect on the development of agricultural production. And the efficiency of rural financial system indicators is positively correlated with agricultural production. This suggests that $1 \%$ increase in rural financial system efficiency can significantly promote the agricultural production by $1.309 \%$.

\subsection{Vector error correction model}

Because all the variables are integrated sequences of order 1, I(1) and there is a co-integration relationship among them, vector error correction model must be built, according to the Granger theorem proposed by Engle and Granger [7]. Based on vector error correction model, we can understand the short-term dynamic relationship between these variables further; the relationship of error correction term can be represented as

$$
\begin{aligned}
& \Delta \mathrm{LnAD}_{t}=\underset{[0.39]}{0.016}-0.1 \mathrm{ECT}_{t-1}+0.184 \mathrm{LnAD}_{t-1}-0.377 \Delta \mathrm{LnRE}_{t-1} \\
& +0.197 \Delta \mathrm{LnPI}_{t-1}+1.024 \Delta \mathrm{LnDE}_{t-1}-1.001 \Delta \operatorname{LnDS}_{t-1}+0.04 \Delta \mathrm{DST}_{t-1} \\
& \mathrm{ECT}_{t}=-9.404+\mathrm{LnAD}-0.186 \mathrm{LnRE}+0.135 \mathrm{LnPI}_{t}+1.652 \mathrm{LnDS}_{t} \\
& +0.063 \operatorname{LnDST}_{t}-1.309 \mathrm{LnDE}_{t} \\
& \text { [1.41] [9.74] } \\
& \text { [7.04] } \quad[-7.69]
\end{aligned}
$$

It is concluded from the equations (4) and (5), the coefficient of error correction term is -0.1 , which is significant at $5 \%$ level. The results above means that the short-term agricultural development deviate from the long-term equilibrium exists to reverse adjustment mechanism of equilibrium, but due to the adjustment of the strength of the small, rural development and in addition to the variables efficiency DST was established under the $10 \%$ significant level, the other variable does not have obvious effect on agricultural development in the short term. Therefore, it is difficult for the system to return to equilibrium automatically, and there is a need for external forces.

\subsection{The Granger short- and long-term causality test based on VEC model}

Feldstein and Stock [8] argue that if there is a co-integration relationship between non-stationary variables, research should be considered using the Granger causality tests based on VEC model (Table 3). It means we cannot eliminate error correction terms in the model, otherwise there may be deviation. Therefore, using the short-term and long-term Granger causality tests based on VEC model for further characterization is necessary. 
Table 3: The Granger short- and long-term causality tests based on VEC model.

\begin{tabular}{|c|c|c|c|c|c|c|c|c|}
\hline Consequences & $\Delta \mathrm{LnAD}$ & $\Delta \mathrm{LnRE}$ & $\Delta \mathrm{LnPI}$ & $\Delta \mathrm{LnDE}$ & $\Delta \mathrm{LnDS}$ & $\Delta \mathrm{LnDST}$ & $\begin{array}{c}\text { Joint } \\
\text { inspection }\end{array}$ & $\mathrm{ECM}_{t-1}$ \\
\hline \multirow[t]{2}{*}{$\chi^{2} P$-value } & - & 0.75 & 0.30 & 1.15 & 0.77 & 2.74 & 3.00 & -0.83 \\
\hline & - & 0.39 & 0.59 & 0.28 & 0.38 & 0.10 & 0.70 & $(-2.52) *$ \\
\hline \multirow[t]{2}{*}{$\chi^{2} P$-value } & 0.72 & - & 0.28 & 4.82 & 7.08 & 2.39 & 11.45 & -0.80 \\
\hline & 0.40 & - & 0.60 & $0.03 *$ & $0.01 *$ & 0.78 & $0.04 *$ & $(-2.68)^{*}$ \\
\hline \multirow[t]{2}{*}{$\Delta \mathrm{LnPI}$} & 0.02 & 0.02 & - & 2.22 & 1.09 & 2.17 & 6.43 & -0.68 \\
\hline & 0.90 & 0.90 & - & 0.14 & 0.30 & 0.14 & 0.27 & $(-2.23)^{*}$ \\
\hline \multirow[t]{2}{*}{$\Delta \mathrm{LnDE}$} & 1.38 & 2.65 & 0.00 & - & 1.40 & 2.65 & 5.96 & 0.25 \\
\hline & 0.24 & 0.10 & 0.99 & - & 0.24 & 0.10 & 0.31 & -1.59 \\
\hline \multirow[t]{2}{*}{$\Delta \mathrm{LnDS}$} & 1.07 & 1.45 & 0.05 & 0.81 & - & 1.24 & 2.13 & 0.11 \\
\hline & 0.30 & 0.23 & 0.82 & 0.37 & - & 0.27 & 0.83 & -0.73 \\
\hline \multirow[t]{2}{*}{$\Delta \operatorname{LnDST} \chi^{2} P$-value } & 1.41 & 0.07 & 0.12 & 0.08 & 0.19 & - & 2.28 & 1.59 \\
\hline & 0.23 & 0.29 & 0.59 & 0.78 & 0.66 & - & 0.81 & -0.46 \\
\hline
\end{tabular}

The variables $\Delta \mathrm{LnDE}$ and $\Delta \mathrm{LnDS}$ are the short-term Granger reasons for $\Delta \mathrm{LnRE}$. And joint inspection shows that variables $\Delta \mathrm{LnRE}, \Delta \mathrm{LnPI}, \Delta \mathrm{LnDE}, \Delta \mathrm{LnDS}$ and $\Delta \mathrm{LnDST}$ constitute the Granger reasons for $\Delta \mathrm{LnRE}$. This means that the efficiency and the scale of rural financial system is the shortterm Granger cause of rural economic growth. At the same time, the rural financial system development, agricultural development and farmers' income are the Granger causes of rural economic growth. The development of rural financial system has a positive effect on rural economic growth. $\triangle \mathrm{LnDST}$ is the Granger reason for $\Delta \mathrm{LnAD}$. It shows that the optimization of rural financial system structure will promote the development of agriculture. Rural economy variables are not the Granger reasons for the variables of rural financial system. Therefore, in the short term, the development of rural financial system and rural economy is a one-way Granger reason, named the development of the rural financial system. The scales of rural finance and the efficiency of rural finance are the keys to promote the growth of the rural economy significantly.

In the long term, because $\Delta \mathrm{LnAD}, \Delta \mathrm{LnRE}$ and $\Delta \mathrm{LnPI} T$-values of the error correction term are larger than 2, the variables $\Delta \mathrm{LnDE}, \Delta \mathrm{LnDS}$ and $\Delta \mathrm{LnDST}$ of rural financial system are related to the variables $\Delta \mathrm{LnAD}, \Delta \mathrm{LnRE}$ and $\Delta \mathrm{LnPI}$ of rural economy. For a long time, there exists a one-way Granger causality between the rural financial development and the rural economic system. That means the efficiency in improving the rural financial system, rural financial deepening and the improvement of the rural financial system structure can improve the growth of the rural economy, agricultural development and farmers' income significantly.

\subsection{Impulse response analysis based on VEC model}

The results of the Granger causality test only show the short- and long-term causal relationship between variables, rather than the strength and path of the causal relationship between variables. Therefore, we should use the impulse-response-function based on VEC model. Impulse response function reflects the size of a standard deviation from a random perturbation term new interest rates impact influence on endogenous variable current and future value, and it affects the path of change. 

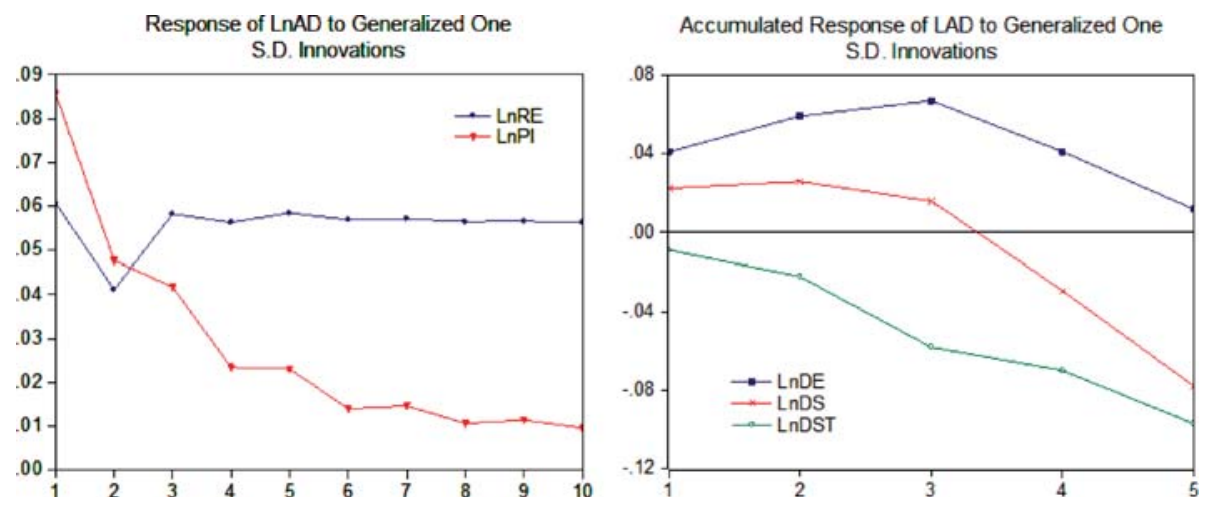

Figure 1

As shown in Fig. 1, after the impact of the rural economy, agricultural development experienced two phases of short wave and enters the first-phase level near 0.06. The impacts from farmers' income help agricultural development reach the first-phase response peak value. After three-period declining significantly, the level of decline eased to around 0.01. It shows that agricultural development of rural economy and farmers' income will generate positive response after the impact. The rural economy growth played a steady part in promoting agricultural development. Although the farmers' income played a positive role in agricultural development in the short term, this effect is weakened gradually as it continues.

\section{CONCLUSIONS}

By using the VEC model, co-integration analysis and impulse response method in rural areas of Heilongjiang province, we can draw the following conclusions according to the empirical analysis:

There exists a long-term equilibrium relationship of co-integration between the development of rural financial system and rural economic growth in Heilongjiang province. The scale and the structure of rural financial system have negative effect on the development of agricultural production. And the efficiency of rural financial system indicators is positively correlated with agricultural production.

There is one-way Granger causality relationship between the development of rural financial system and rural economy. That means the improvement of efficiency of rural financial system, the rural financial deepening and the improvement of the rural financial system structure can improve the growth of the rural economy, agricultural development and farmers' income significantly. In the short term, there is a one-way Granger causality relationship between the development of rural financial system and the rural economy. It means scales and efficiency in improving the rural financial system are the keys to promote the growth of rural economy significantly. To improve the service efficiency of rural financial institutions and to guarantee the efficiency of rural financial system, efficient operations are the effective measures to sustain the rural economic growth.

\section{REFERENCES}

[1] Han, T., Financial ecological environment influence on the development of financial markets. The Journal of World Economy, 3, 2008.

[2] Nie, H., The empirical analysis of rural financial development and economic growth in Heilongjiang province. Farm Economic Management, 3, 2009. 
[3] Yu, Y., Research on the relationship between rural financial development and rural economic growth based on VAR models. Economic Problems, 12, 2011.

[4] Ding, Z., Does rural finance efficiently improve the development of rural economic in China. Issues in Agricultural Economy, 9, 2012. doi: http://dx.doi.org/10.2307/1912517

[5] Huang, Y., Problems of deepening reform of the rural financial system. China Rural Finance, 1, 2013.

[6] Dickey, D.A. \& Fuller, W.A., Likelihood ratio statistics for autoregressive time series with a unit root. Econometric, 49, pp. 1057-1072, 1981.

[7] Engle, R.F. \& Granger, C.A.J., Co-integration and error correction: representation, estimation and testing. Econometric, 55, pp. 251-276, 1987. doi: http://dx.doi.org/10.2307/1913236

[8] Feldstein, M.S. \& Stock, J.H., The use of a monetary aggregate to target nominal GNP. Monetary Policy, ed. N.G. Mankiw. University of Chicago Press: Chicago, 1994. 